\title{
Development of Technological Efficacy via an E-learning Programme: South African Parliament Employees
}

\author{
Fikile Mbuli \\ 19 Villa Marina, Beach Road, Mouillepoint, 8005
}

\begin{tabular}{|c|c|}
\hline \multicolumn{2}{|c|}{ Department of Adult Education and Youth Development, University of South Africa, } \\
\hline Article history & In June 2011 , the Parliament of the Republic of South Africa (RSA) s \\
\hline Received: & up an 18-month pilot e-learning programme for staff working in its \\
\hline 27.08 .2015 & Language Services section. The curriculum for this programme included \\
\hline $\begin{array}{l}\text { Received in revised form: } \\
15.09 .2015\end{array}$ & $\begin{array}{l}\text { subjects such as general management, leadership, people management, } \\
\text { public financial management, project management, and economics. At } \\
\text { the end of } 2012 \text {, Mbuli conceived and designed a questionnaire-based }\end{array}$ \\
\hline $\begin{array}{l}\text { Accepted: } \\
16.09 .2015\end{array}$ & $\begin{array}{l}\text { study (that is, a survey) to explore learners' experiences of the } \\
\text { programme. One of the findings that emerged from this study was that }\end{array}$ \\
\hline Key words: & involvement in the programme helped employees to gain technical skills \\
\hline $\begin{array}{l}\text { e-learning experiences; } \\
\text { technological efficacy; } \\
\text { learner preparedness; } \\
\text { enskilling in ICT. }\end{array}$ & $\begin{array}{l}\text { related to ICT. The vast majority of participants indicated that their } \\
\text { participation in the programme increased their desire to improve their } \\
\text { ICT skills, skills that they could apply in their work activities. That is, } \\
\text { they became motivated to improve their technological efficacy, which } \\
\text { was helpful to them for participation in the course and for work-related } \\
\text { activities. This article discusses this outcome of the "academic" syllabus, } \\
\text { and suggests that encouraging the development of technological efficacy } \\
\text { should be given more attention in this, as in other, e-learning } \\
\text { programmes. It is suggested that learners enrolling for e-learning } \\
\text { programmes can benefit from more preparatory guidance to prepare them } \\
\text { for an understanding of the e-learning context. }\end{array}$ \\
\hline
\end{tabular}

\section{Introduction}

As Hiralaal observes, "times are changing for higher education with ... an [increasing] emphasis on producing learning and expanding education using technology-mediated learning" (Hiralaal, 2012, p. 318). She indicates that this emphasis in South Africa (as in other parts of the globe) is consistent with the South African Department of Education's White Paper on E-learning (2003, pp. 19-20), in which it is suggested that e-learning encourages "learner-centred teaching, and active exploratory inquiry-based learning" (whether or not combined with face-to-face connections as in blended learning).

Naidu likewise indicates that, across the globe, "campus-based and face-to-face educational practice is increasingly becoming unsustainable" (2014, p. 269). He argues that financial

\footnotetext{
*Correspondence: P.O. Box 392, Pretoria 0003 Email: norma.romm@gmail.com or rommnra@unisa.ac.za Phone:
} +27824060585 Fax: +27865543978 
pressures, along with the increasing availability of information and communication technologies, are the prime reasons for this change. In discussing the evolution of distance education (DE), Baggaley (2008, p. 40) points out that "DE methods have acquired a level of cost-effectiveness that provides teachers and students with a broad selection of methods for overcoming the obstacles of time, place, and pace while also engaging one another in direct interaction". In the case of South Africa's parliamentary employees, the DE e-learning programme offers a unique opportunity for employees working in Parliament to engage in further education, where the learning is also integrated into their work activities via an inhouse programme (which is handled via the University of Stellenbosch). However, Baggaley, in looking at what can "go wrong" within distance education options in different parts of the globe, cautions that we also need to consider how DE approaches are used, since they are not "used uniformly in individual DE institutions and cultures" (2008, p. 40). Baggaley states that issues regarding the use of appropriate technology remain challenges to be addressed (2008, p. 41).

According to Mugarura (2010, p. 14), developing countries do not have all the advantages of developed countries when it comes to the processes of e-learning. Developing countries still lack access to high-speed internet, uninterrupted electricity, and inexpensive low bandwidth satellite technology; these countries also suffer from a dearth of adequately trained personnel. The parliamentary employees were asked in Mbuli's study to answer questions relating to their e-learning experiences, including questions relating to technical facilities and support. Whether and to what extent technical issues were a problem for the participants in the study were thus considered, as were questions regarding employees' confidence and enhancement of ICT capacities.

\section{Theoretical Considerations}

In reflecting on the philosophy of education underlying DE, Hiralaal claims that "the changing face of higher education" implies that learning theories such as social constructivism are specifically pertinent to the current era (2012, p. 320). Holzweiss et al. (2014, pp. 212-213) indicate that such theories concentrate on how learners are actively involved in creating knowledge based on their "direct experiences" (such as work experiences in the case of Mbuli's study of parliamentary employees), and on their "collaboration with others" (in this case, workplace peers). As theoretical approaches to learning processes, constructivist arguments suggest that learners are not passive recipients of supplied course material, but that learners can and do create meaning (individually and collectively) in relation to this course material. Duffy and Kirkley, concentrating on developments in the United States, propose that one can deliberately create distance education programmes in which learners are encouraged to participate in the learning experience by bearing in mind "the principles for the design of a learner-centred or constructivist distance learning environment" (2004a, p. 10). Taking a similar line of argument, Matodzi, Herselman, and Hay, writing in the context of adult education in South Africa, suggest that e-learning can develop learners' skills to "work together in problem-solving, tracking their progress and their abilities, and building a personalized learning path based on their particular goals" (2007, p. 71).

This is not to say that this is the case in all e-learning programmes. Cook, et al. point out that, in the United States, for example, as elsewhere, many graduate programmes that include online components "are instructor-centered, often modeling traditional-styled "knowledge transmission"” (2011, pp. 73-74). Given this, Cook et al. suggest that "effective teaching and 
learning in distributed education programs must engage students in socially interactive learning environments where students co-construct understandings with both instructors and peers" (2011, p. 74). For a constructivist-oriented environment to be fostered, as MacDonald notes, a (re)consideration is needed of the ways in which the educational environment is "constructed, organized, structured, governed and financed" (2001, p. 153).

A myriad of authors have written about the potential to construct learner-centred learning experiences via e-learning (cf. Albert \& Campbell, 2008; Almala, 2006; Anderson, 2010; Duffy \& Cunningham, 1996; Duffy \& Kirkley, 2004b; McCombs \& Vakili, 2005; McIntyreMills et al., 2014; Veletsiano, 2010). But Aluko contends that research on the (experienced) impact of distance education programs on learners is as yet "sparse" (2009, p. 2). And Holzweiss et al. add that perceptions of learning in online environments as seen by the learners themselves are difficult to find-“especially perceptions of students in graduate studies" (2014, p. 313). From their own qualitative study set in the United States, five themes emerged as being important for students: (a) critical thinking assignments, (b) instructional technology, (c) faculty engagement, (d) interactions with peers and instructors, and (e) personal responsibility. One of the themes which is pertinent to this article is "instructional technology". Markedly, they note that findings in this regard were that students who had "more experience with online courses or are further along in their educational programmes may benefit more from participating in discussion forums than students who are new to distance education or to the academic discipline" (2014, p. 316). This result is also relevant to what was found in the study by Mbuli $(2013$, p. 85) in relation to learner confidence and how this increased through the experience of involvement in the programme.

Lemos and Pedro offer another example of seeking to examine the experiences of graduate online learners - that is, those involved in a master's degree in Education at a university in Portugal. They concentrated on the "infra-structures and technological aspects, such as the website or learning management system which supports the e-learning courses, its usability, [and] its user-friendly interface" (2012, p. 1109). Their conclusion was that, if such factors are overlooked by designers of programmes, they will "act as critical barriers" (2012, p. 1109).

\section{Research Questions}

The question remains as to what level of technological proficiency and confidence in using ICT a learner might require so that $\mathrm{s} / \mathrm{he}$ feels that s/he can participate actively in the elearning environment (in accordance with constructivist principles). And further to this, the question can be asked as to how participation in e-learning processes, might improve such proficiency. Naidu (2014b, p. 2) suggests that one angle to take on these questions is to recognize that "what works" in distance education must also be regarded as a function of students being motivated to make it work. He suggests that the concept of "learner agency" allows us to explain how students are impelled to "persist in learning independently" (Naidu 2014 b, p. 2). However, this does not mean that one can forego considerations of how to enable students to operate in an e-learning environment, a point also emphasized by Breen et al. (2001, p. 110) and by Parkes, Stein, and Reading (2015, p. 8). This article attempts to make a contribution to the literature by focusing on South African parliamentary employees' answers to questions about their e-learning experiences. It concentrates on whether participation in the e-learning course can be said to have resulted in acquisition of technological skills, as part of the process of learners' being actively involved in the learning process. 


\section{The Study}

\section{Some Background}

The Parliament of the Republic of South Africa subsidized employees working in its Languages Services section to enrol for the e-learning programme (which started in 2011), in order to fast-track the upgrading of Parliament's language practitioners. This decision was also taken in order to comply with government skills development policy and to promote the effectiveness and efficiency of the work undertaken by the South African Parliament. Enrolment in the course was voluntary. The learners who participated received modules online. These learners had contact with the lecturers from the University of Stellenbosch using different types of communication methods such as emailing, telephoning and the use of short message systems. The employees were encouraged to form study groups, and they were also able to ask lecturers to come and address them as a group if needed. Assessment was online. They had access to computers supplied by Parliament and they also had access to the internet.

Some of the research questions on which Mbuli concentrated in the study were: whether the parliamentary employees developed their skills as a result of this (pilot) e-learning programme and whether the employees felt more able to discharge their responsibilities successfully as a result of what they have learned from the programme (Mbuli, 2013, p. 10). This article focuses on putting forward various interpretations and inferences in relation to these questions, based on the results of this study, particularly in regard to the question of the learners' enhancement of technical capabilities.

\section{Study Participants}

The population of this study consists of those parliamentary Language Services employees who participated in the learning programme. In total, 163 employees participated in the programme (lower- and middle-management level and administrative employees). For the purposes of this study, Mbuli decided to distribute the questionnaire to all of these learners (rather than draw a sample). The Language Services Section consists of three components: Reporting, Translation and Interpreting Units. These units between them employ 200 people, of whom 163 participated in the learning programme discussed here. The questionnaires were distributed to all 163 employees and the response rate was $100 \%$. Mbuli surmises that because she was "familiar with the operations of the Language services section due to having acquaintances and friends in this section ... this was likely to be a factor that improved the response rate of people responding to the questionnaire that was distributed" $(2013,11)$.

The first few questions of the questionnaire related to participants' biographical information. It turned out that, of the 163 participants, $33.1 \%$ were males and $66.3 \%$ were females. (One respondent did not specify his/her gender.) As far as educational qualifications are concerned, most participants possessed an honours degree (32.5\%). This percentage was followed by employees whose highest level of education was a junior degree $(28.8 \%)$, followed by those with diplomas (11.0\%). Only $4.9 \%$ had no tertiary qualifications and about $0.6 \%$ had a Ph.D degree. In terms of years of educational experience, $36.2 \%$ of respondents had less than 5 years' educational experience, $51.5 \%$ had 6 to 10 years' educational experience, $8.6 \%$ respondents had 11 to 15 years, and $3.7 \%$ had 16 to 20 years' educational experience. Work experience was as follows: $32.3 \%$ had less than 5 years of work experience in Parliament, a further $32.3 \%$ had been employed there for 6 to 10 years, $26.8 \%$ had been employed there for 11 to 15 years and $7.9 \%$ had been employed for 16 to 20 years. 


\section{The Questionnaire}

Space does not permit us to give an account of all of the questions posed in the questionnaire. So we shall concentrate only on those questions that directly relate to the issues examined in this article. Before moving on to discuss these questions, it is worth mentioning that Mbuli piloted the draft questionnaire to see how long it would take to complete the questionnaire and to find out whether there were any deficiencies in the construction of the questions. Eight people who were going to be part of the study filled in the draft questionnaire and offered suggestions for changes, including suggestions for shortening it. The final questionnaire consisted of 18 questions, with a few of these questions being openended. Finally, at the end of the questionnaire there was a note to participants asking them to comment on their experience of filling in the questionnaire. This note was phrased as follows: "Please note: I am interested to know also what your experience was of filling in this questionnaire. Did the questions help you to think further about any of the issues? Please write any comments that you may have."

The type of comments that were elicited from respondents who responded to this final note (16 of them) indicated that they had learned about e-learning by having to think about the questions asked in the questionnaire. This tallies with Daniels' suggestion that research itself can and should "stimulate reflection", which enables participants to learn from the research encounter (2010, p. 10). Although Daniels discusses this in the context of doing qualitative research, Romm suggests that the encouragement of reflection can also apply to the handling of quantitatively-directed research (Romm, 2013, 2014). In essence, the research style used by Mbuli sought mainly descriptive numerical data, which is in keeping with Denzin and Lincoln's observation that "many qualitative researchers in the postpositivist tradition will use statistical measures, methods and documents as a way of locating groups of subjects", but will seldom try to undertake "path, regression or log-linear analysis" to locate "causality" in the social world (2003, p. 15). The research conducted by Mbuli can be said to fit this category. (Again, space in this article does not permit a discussion of how one can conceive the research as fitting in with a postpositivist tradition that does not search for value-neutrality. For more detail on postpositivist and qualitative arguments regarding the status of findings sought in research and/or evaluation processes, see Gregory, Romm \& Walsh, 1994; Romm, 1996, 2001, 2013.)

For the body of the questionnaire, Mbuli asked respondents to respond to questions such as whether they could apply e-learning methods to their work situation, whether they felt deprived of face-to-face contact with an instructor, whether they felt motivated to improve their ICT skills, etc. (These issues were based on a reading of the literature.) Other questions asked respondents to consider the e-learning experience in terms of the following: whether they feel that they were independent learners; whether they were capable of working and studying at the same time; whether e-learning prepared them to handle difficult work-based challenges; whether they feel confident to be part of a discussion and dialogue groups; whether it is easy to relate the content of the study with their work; whether they feel that they can get support when they are studying and have doubt and difficulties; whether they enjoy their studies more than when they started; whether they feel that they are able to assist their fellow learners with their studies; and whether they feel that they can ask for assistance from fellow learners. Furthermore, questions targeting respondents' perceptions of "supporting resources" were also constructed. One such question asked respondents to answer affirmatively or negatively to the following statements: "There was someone to assist you with all e-learning education challenges"; "Learning resources such as the internet, intranet and knowledge management resource were available"; "There is access to your institution 
(university or other) and other libraries that are in partnership with your institution”.

Although some open-ended questions were asked in the questionnaire, these did not elicit many responses, excepting that one of the questions that asked them to comment on what they most enjoyed about the e-learning experience elicited 11 responses (mainly referring to the fact that they enjoyed being in control of their time and having the opportunity for independent study). A final question asked them whether they felt confident taking part in education using e-learning methods (with options being "very confident", "fairly confident" and "not at all confident").

This article focuses on the distribution of responses to the various questions, taking into consideration issues of technical ability and the influence of the e-learning programme on respondents' confidence. It should be emphasized that we are not claiming that the "findings" as offered below are free of the influence of the specific way of constructing the questions and the researchers' specific way of applying their interpretive skills to the "results". Here we concur with Daniels that "researchers are similar to explorers who seek to make meaning of the worlds of others" (2010, p. 8). We consider that it is important to admit that the findings emerged as a situated product of respondents/participants responding to particular framings as provided in the context of this questionnaire. Furthermore, our interpretation is also based on reading the findings in the light of our "giving meaning". (See also Romm, 2001, p. 201; 2002a, p. 60; 2002b, p. 461; 2010, p. 213.) In this case, we present our understandings as offering credible accounts, rather than as the only possible interpretations that could be offered, a position also recommended by Lincoln and Guba (2013, p. 104).

\section{Some Analyses and Interpretations of Findings}

\section{Levels of Satisfaction with E-learning}

One question in the questionnaire was specifically constructed to gauge respondents' levels of satisfaction with aspects of the e-learning experience. Responses were distributed as shown in Table 1.

Table 1: Satisfaction with E-learning

\begin{tabular}{|c|c|c|c|c|c|c|c|c|}
\hline \multirow[t]{2}{*}{$\begin{array}{l}\text { Level of } \\
\text { satisfaction }\end{array}$} & \multicolumn{2}{|c|}{$\begin{array}{l}\text { E-learning } \\
\text { technology }\end{array}$} & \multicolumn{2}{|c|}{ Learning material } & \multicolumn{2}{|c|}{ Learning content } & \multicolumn{2}{|c|}{$\begin{array}{c}\text { Improvement of } \\
\text { education standards }\end{array}$} \\
\hline & $\mathrm{N}$ & $\%$ & $\mathrm{~N}$ & $\%$ & $\mathrm{~N}$ & $\%$ & $\mathrm{~N}$ & $\%$ \\
\hline Good & 148 & 90.8 & 150 & 92.0 & 147 & 90.2 & 157 & 96.3 \\
\hline Fair & 13 & 8.0 & 11 & 6.7 & 12 & 7.4 & 6 & 3.7 \\
\hline Poor & 2 & 1.2 & 2 & 1.2 & 4 & 2.5 & 0 & 0 \\
\hline Total* & 163 & 100.0 & 163 & 100.0 & 163 & 100.0 & 163 & 100.0 \\
\hline
\end{tabular}

This table indicates that the majority of participants were satisfied with all selected e-learning aids and standards (such as e-learning technology, learning material, learning content and improvement of educational standards). More than $90 \%$ of employees felt that e-learning technology, learning material, learning content and improvement of education standards were good: $90.8 \%, 92.0 \%, 90.2 \%$ and $96.3 \%$ respectively. Only a minority of participants felt that these were fair or poor. This suggests that the majority of participants were sufficiently computer literate to benefit from the programme and could apply this literacy both in their elearning programme and in their work situations. This interpretation could also account for the distribution of responses to the question in the questionnaire which asked them about elearning in the workplace, where $90.8 \%$ strongly agreed that they can apply "the e-learning methods gained through e-learning to my work", as shown in Table 2 below. And, more 
importantly, as far as this article is concerned, 89\% strongly agreed that their e-learning programme "made me to have desire to enhance my ICT skills"; while a further 9\% agreed with this statement. This means that the vast majority were motivated to acquire ICT skills through participation in the programme and this, in turn, had an effect on their work performance. As Mbuli explains, with reference to Table 2:

Since email was not the only method of communication, the employees explored other types of communication technologies as the time went on and as they got more experienced with their learning method which added value to the quality of their education and made them realize that they can implement the skills they acquired during their studying to their everyday jobs (2013, p. 63).

Table 2: E-learning Experience

\begin{tabular}{|c|c|c|c|c|c|c|c|c|c|c|}
\hline \multirow[t]{2}{*}{ Statements } & \multicolumn{2}{|c|}{$\begin{array}{l}\text { Strongly } \\
\text { disagree }\end{array}$} & \multicolumn{2}{|c|}{ Disagree } & \multicolumn{2}{|c|}{ Not sure } & \multicolumn{2}{|c|}{ Agree } & \multicolumn{2}{|c|}{$\begin{array}{c}\text { Strongly } \\
\text { agree }\end{array}$} \\
\hline & $\mathrm{N}$ & $\%$ & $\mathrm{~N}$ & $\%$ & $\mathrm{~N}$ & $\%$ & $\mathrm{~N}$ & $\%$ & $\mathrm{~N}$ & $\%$ \\
\hline $\begin{array}{l}\text { There were limitations } \\
\text { in using a computer at } \\
\text { work. }\end{array}$ & 152 & 93.3 & 6 & 3.7 & 1 & 0.6 & 0 & 0 & 4 & 2.5 \\
\hline $\begin{array}{l}\text { There were limitations } \\
\text { in using a computer } \\
\text { during my studies. }\end{array}$ & 98 & 60.1 & 35 & 21.5 & 0 & 0 & 7 & 4.3 & 22 & 13.5 \\
\hline $\begin{array}{l}\text { E-learning is the } \\
\text { expensive method of } \\
\text { studying. }\end{array}$ & 149 & 91.4 & 10 & 6.1 & 3 & 1.8 & 0 & 0 & 0 & 0 \\
\hline $\begin{array}{l}\text { I cannot use a } \\
\text { computer. }\end{array}$ & 147 & 90.2 & 13 & 8.0 & 2 & 1.2 & 0 & 0 & 0 & 0 \\
\hline $\begin{array}{l}\text { I used only email to } \\
\text { communicate and } \\
\text { share information with } \\
\text { my study group. }\end{array}$ & 8 & 4.9 & 137 & 84.0 & 9 & 5.5 & 6 & 3.7 & 2 & 1.2 \\
\hline $\begin{array}{l}\text { E-learning added value } \\
\text { to quality of my study } \\
\text { programme. }\end{array}$ & 0 & 0 & 2 & 1.2 & 6 & 3.7 & 12 & 7.4 & 142 & 8.1 \\
\hline $\begin{array}{l}\text { I will apply the E- } \\
\text { learning methods } \\
\text { gained through E- } \\
\text { learning to my work. }\end{array}$ & 2 & 1.2 & 0 & 0 & 8 & 4.9 & 4 & 2.5 & 148 & 90.8 \\
\hline $\begin{array}{l}\text { I did not feel deprived } \\
\text { of face-to-face contact } \\
\text { with the instructor. }\end{array}$ & 0 & 0 & 35 & 21.5 & 2 & 1.2 & 37 & 22.7 & 88 & 54.0 \\
\hline $\begin{array}{l}\text { The E-learning } \\
\text { programme made me } \\
\text { to have desire to } \\
\text { enhance my ICT skills. }\end{array}$ & 0 & 0 & 2 & 1.2 & 0 & 0 & 15 & 9.2 & 145 & 89.0 \\
\hline $\begin{array}{l}\text { E-learning courses are } \\
\text { not inferior to formal } \\
\text { classroom courses. }\end{array}$ & 0 & 0 & 0 & 0 & 20 & 12.3 & 37 & 22.7 & 105 & 64.4 \\
\hline
\end{tabular}

It is worth highlighting from this table that $91.4 \%$ of the participants answered negatively to the statement that there was someone from the educational institution who could assist with elearning challenges. Furthermore, respondents did not feel comfortable in asking peers for assistance, as can be seen from responses to another question that gave them the option to "tick" whether they feel that they can ask for assistance from a fellow learner. Only $2.5 \%$ ticked this response option. It seems that they were reluctant to ask fellow students when it came to "technical assistance". 
Table 2 does offer the finding that more than half of the respondents strongly agreed that they did not feel deprived of face-to-face contact with the instructor, and $22.7 \%$ of respondents agreed with this statement. Nevertheless, it should be noted that $21.5 \%$ disagreed. According to the programme design, the employees could contact their instructors when they needed but, for some participants, this was inadequate. Also, as Mbuli indicates, "those who struggled with technology and joining online dialogues and discussions missed and felt deprived of physical contact with instructors and fellow learners" (2013, p. 64). This points to the worthiness of heeding Parkes et al.'s caution that learners who are (relatively) new to elearning environments may need to develop their "preparedness" (using institutional support that is made available) for participating in online learning (2015, p. 7). Craig notes in this regard, though, that it is not only students, but also staff, who may need to develop new skills in e-learning activities so as to assist students in this regard $(2010$, p. 3$)$.

\section{Learners' Sense of Confidence}

A final quantitatively-designed question that appeared in the questionnaire asked respondents the question "Do you feel confident in taking part in education using e-learning methods? Table 3 below depicts responses.

\begin{tabular}{|c|c|c|}
\hline Statements & $\mathrm{N}$ & $\%$ \\
\hline Not at all confident & 37 & 22 \\
\hline Fairly confident & 6 & 04 \\
\hline Very confident & 120 & 74 \\
\hline
\end{tabular}

Table 3 can be interpreted as showing that e-learning was a success as far as the vast majority of respondents were concerned in the sense that, reflecting on the experience, $74 \%$ of respondents felt that they were equipped to participate; that is, they felt very confident about their ability to take part in e-learning processes. We can also suggest that the parliamentary employees who feel either very confident or fairly confident will now feel more "prepared" to participate in further e-learning education in future. (This is supported by statements that a number of respondents made when offering feedback on their experience of filling in the questionnaire.)

\section{Experience of Filling in the Questionnaire: Feedback}

A closing note in the questionnaire was aimed at soliciting feedback from respondents about their experience of completing the questionnaire. Sixteen respondents offered comments. Nearly all of them indicated that, just by reading the questions and having to reflect on these questions in order to provide answers, was in itself a learning experience. Below we concentrate on their comments (and make inferences for the purposes of this article).

Most of the respondents said the survey made them mindful of what e-learning is and what it is about. Comments received were: "This questionnaire made me to be aware about elearning. I had never given myself time to think about e-learning and what it's about"; "Filling in this questionnaire made me feel that I don't know much about e-learning and its benefits to me as a learner"; "Filling in this questionnaire made me to understand the meaning of e-learning and distance education"; "This questionnaire taught me what e-learning is all about; I knew about e-learning and distance education and now I see how it really works"; 
"The questionnaire was long but very informative at the same time. I learnt a lot from the issues mentioned here"; "Filling in this questionnaire made me realize that I have been very ignorant about e-learning". "I was not aware that I can add more information to the study material I get when I register for a course"; "This questionnaire opened my eyes. Filling in this questionnaire was a learning journey for me. I was not aware of a lot of issues that are mentioned in this questionnaire".

These types of comments suggest that, if the respondents had been exposed in some way to the issues mentioned in the questionnaire before they started the e-learning programme, such exposure would have been of benefit to them.

What is also noteworthy is that many respondents said that the questionnaire was an inspiration to them to study further: "Filling in this questionnaire made me to realize that through e-learning I can be able to study further without relying on the programmes offered at work. I want to know about more benefits of e-learning. I feel motivated to study further using my computer skills"; "I feel confident about my abilities in education. I am motivated to learn more through distance education"; "After filling in this questionnaire I thought about my distance education I have been doing and realized that I need to learn more about elearning to make my future studies to be more easier".

In summary, respondents who chose to comment on their experience of filling in the questionnaire indicated that the questionnaire alerted them to issues that they had not reflected upon before. Filling in the questionnaire also made them realize that there is more to find out about e-learning than they had originally realized. Apart from this implying that they experienced the questionnaire instrument as a way of enhancing their understanding of elearning, it also shows that e-learners who are, or plan to be, involved in an e-learning programme can benefit from an increased acquaintance with what is involved in e-learning.

\section{Conclusions and Recommendations}

The vast majority of those who participated in this e-learning programme developed a desire during their studies to improve their ICT skills so that they could better participate (with $89 \%$ of participants strongly agreeing and $9 \%$ agreeing that this was the case). These skills became improved to the extent that, when asked in a further question about their satisfaction with the e-learning programme, $90.8 \%$ stated that the technological aspect of the programme was "good". Nonetheless we would argue that this does not relinquish the educational institution's responsibility to help them become able ICT learners. This study provides an indication of learners' appreciation of improved ICT skills (and how they can also use such skills in the workplace) as a result of participating in an e-learning programme. That said, most participants seemed to have missed having someone who was available to help them when they encountered difficulties.

We therefore recommend - along with other authors such as Parkes et al.- that for this, as for other e-learning programmes, more attention needs to be given by the relevant educational institution to improving learner "preparedness" (2015, p. 7). Kirkwood and Price also suggest (based on their research at the Open University in the United Kingdom) that, because an important function of the educational use of ICT is to "actively engage learners", they may need to be helped to "achieve desired goals" (2005, p. 268).

Wang, Shannon, and Ross (2013, p. 302) suggest that workshops are a viable way of handling this, and we would agree with this recommendation. We also recommend that staff dedicated 
to assisting learners with e-learning challenges be available. In the case of this study of South African parliamentary employees, it is clear that an improvement in their ICT skills was an important byproduct of this e-learning programme, and that this in itself helped the learners with their work. Given the importance, in the current era, of such computer ability as part of the development of our knowing/learning processes in nearly all work situations, we propose that this aspect should indeed be seen as part of the "curriculum" in DE programmes, to further enskill learners in this regard.

\section{References}

Aluko, R. (2009). The impact of an Advanced Certificate in Education (ACE) programme on the professional practice of graduates. International Review of Research in Open and Distance Learning, 10(4), 2-25.

Anderson, T. (2010). Theories for learning with emerging technologies. In G. Veletsianos (Ed.) Emerging technologies in distance education, pp. 23-39. Edmonton: Athabasca University Press.

Almala, A.H. (2006). Applying the principles of constructivism to a quality e-learning environment. Distance Learning, 3(1), 33-40.

Baggaley, J. (2008). Where did distance education go wrong? Distance Education, 29(1), 3951.

Breen, R., Lindsay, R., Jenkins, A., \& Smith, P. (2001). The role of information and communication technologies in a university learning environment. Studies in Higher Education, 26(1), 95-114.

Cook, M., Dickerson, D.L., Annetta, L.A., \& Minogue, J. (2011). In-service teachers' perceptions of online learning environments. The Quarterly Review of Distance Education, 12(2), 73-79.

Craig, J. (2010). E-learning in politics. European Political Science, 9, 1-4.

Daniels, D. (2010). Telling my story: Being a feminist researcher in higher education. South African Journal of Higher Education, 24(1), 5-14.

Department of Education (South Africa). (2003. White Paper on e-Education. Pretoria: Government Printer.

Denzin, N.K., \& Lincoln, Y.S. (2003). Introduction. In N.K. Denzin \&Y.S. Lincoln The landscape of qualitative research: Theories and issues, pp. 1-45. London: Sage.

Duffy, T.M., \&Cunningham, D. (1996). Constructivism: Implications for the design and delivery of instruction. In D.H. Jonassen (Ed.) Handbook of research for educational communications and technology, pp. 170-198. New York: Simon and Schuster.

Duffy, T.M., \& Kirkley, J.R. (2004a). Introduction: Theory and practice in distance education. In T.M. Duffy \& J R. Kirkley (Eds.) Learner-centered theory and practice in distance education, pp. 3-13. Mahwah: Lawrence Erlbaum Associates.

Duffy, T.M., \& Kirkley, J.R. (2004b). Learning theory and pedagogy applied in distance learning: The case of Cardean University. In T.M. Duffy \& J.R. Kirkley (Eds.) Learner-centered theory and practice in distance education, pp. 107-142. Mahwah: Lawrence Erlbaum Associates.

Gregory, W., Romm, N.R.A., \& Walsh, M. (1994). The Trent quality initiative: A multiagency evaluation of quality Standards in the National Health Service. University of Hull: Centre for Systems Studies Press.

Hiralaal, A. (2012). Students' experiences of blended learning in accounting education at the Durban University of Technology. South African Journal of Higher Education, 26(2), 316-328. 
Holzweiss, P.C., Joyner, S.A., Fuller, M.B., Henderson, S., \& Young, R. (2014). Online graduate students' perceptions of best learning experiences. Distance Education, 35(3), 311-323.

Lemos, S., \& Pedro, N. (2012). Improving the quality of e-learning courses in higher education through student satisfaction. World Academy of Science, Engineering and Technology, 66, 1108-1114.

Lincoln, Y.S., \& Guba, E. G. (2013). The constructivist credo. Walnut Creek: Left Coast Press.

Kirkwood, A., \& Price, L. (2005). Learners and learning in the twenty-first century: What do we know about students' attitudes towards and experiences of information and communication technologies that will help us design courses? Studies in Higher Education, 30(3), 257-274.

MacDonald, H.I. (2001). Catching up with e-learning: Implications for education and social policy. Media Asia, 28, 153-156.

Matodzi, T., Herselman, M.E., \& Hay, H.R. (2007). E-learning: An ally in the development of rural South African communities. Journal for New Generation Sciences, 5(1), 69-93.

Mbuli, F. (2013). An evaluation of the influence of e-learning in adult education with special reference to the employees of Parliament RSA. Master's dissertation. University of South Africa.

McCombs, B.L., \& Vakili, D. (2005). A learner-centered framework for e-learning. Teachers College Record, 107(8), 1582-1600.

McIntyre-Mills, J., Mokwena G.K., Arko-Achemfuor A., Mabunda, P., \& Njiro., E. (2014). Participatory approach to education: An action learning approach at the University of South Africa. Participatory Educational Research. 1(2), 106-132.

Mostert, J.W. (2006). The challenges for an African distance education learner: A distance educator's perspective. South African Journal of Higher Education, 20(3), 137-149.

Mugarura, C. (2010). Strategies for deploying e-learning in developing countries. Educational technology debate: Exploring ICT and learning in developing countries. Retrieved 10 November 2012 from http://edutechdebate.org/page/14/?s=EduTechDebate.

Naidu, S. (2014a). Editorial: Looking back, looking forward: The invention and reinvention of distance education. Distance Education, 35(3), 263-270.

Naidu, S. (2014b). Editorial: In search of "what works" in online and distance education. Distance Education, 35(1), 1-3.

Parkes, M., Stein, S., \& Reading, C. (2015). Student preparedness for university e-learning environments. Internet and Higher Education, 25, 1-10.

Romm, N.R.A. (1996). Systems methodologies and intervention: The issue of researcher responsibility. In R.L. Flood \& N.R.A. Romm (Eds.) Critical Systems Thinking: Current research and practice, pp. 179-193. New York: Plenum.

Romm, N.R.A. (2001). Accountability in social research: Issues and debates. New York: Kluwer Academic/Plenum.

Romm, N.R.A. (2002a). Responsible knowing. Philosophy of Management, 2(1), 59-74.

Romm, N.R.A. (2002b). A trusting constructivist approach to systemic inquiry: exploring accountability. Systems Research and Behavioral Science, 19(5), 455-467.

Romm, N.R.A. (2010). New racism: Revisiting researcher responsibilities. New York: Springer.

Romm, N.R.A. (2013). Employing questionnaires in terms of a constructivist epistemological stance: Reconsidering researchers' involvement in the unfolding of social life. International Journal of Qualitative Methods, 12, 652-669.

Romm, N.R.A. (2014). Active and accountable social inquiry: implications and examples. Participatory Educational Research, 1(2), 13-20.

Veletsianos, G. (2010). A definition of emerging technologies for education. In G. Veletsianos (Ed.) Emerging technologies in distance education, pp. 3-22. Edmonton: Athabasca University Press.

Wang, C-H., Shannon, D.M., \& Ross, M. E. (2013). Students' characteristics, self-regulated learning, technology self-efficacy, and course outcomes in online learning. Distance Education, 34(3), 302-323. 